\title{
THE STRATEGIC CHOICES IN ACHIEVING TOURISM'S COMPETITIVENESS AND PERFORMANCE AMONG HOTELS IN INDONESIA
}

\author{
Alim SYARIATI* \\ State Islamic University of Alauddin Makassar, Department of Management, Indonesia e-mail: alim.syariati@uin-alauddin.ac.id \\ Muhammad Yunus AMAR \\ Hasanuddin University, Department of Management, Indonesia e-mail: myunmar@unhas.ac.id \\ Namla Elfa SYARIATI \\ State Islamic University of Alauddin Makassar, Department of Accounting, Indonesia e-mail: namla.elfa@uin-alauddin.ac.id

\begin{abstract}
Citation: Syariati, A., Amar, M.Y., \& Syariati, N.E. (2021). THE STRATEGIC CHOICES IN ACHIEVING TOURISM'S COMPETITIVENESS AND PERFORMANCE AMONG HOTELS IN INDONESIA. GeoJournal of Tourism and Geosites, 38(4), 1223-1231. https://doi.org/10.30892/gtg.38429-763
\end{abstract}

\begin{abstract}
The current debate between external strategy and a resource-based approach as a driver of competitiveness is rarely investigated in a developing region. This study investigates whether an external focus or a resource-based strategy is better for leveraging the hotel industry's competitiveness and performance in a developing area in Indonesia. The authors obtained saturated responses from 204 managers and analyzed them with PLS-SEM's two-stage and repeated indicator approach while interviewing some of them. This study developed a formative model in PLS-SEM as a better method for investigating an organization's performance than a reflective approach. Quantitative analysis revealed the resource-based view as a better basis for supporting hotels' competitiveness and performance; however, the interview revealed considerable concerns over arising externalities. This paper suggests that hotel managers improve their internal core competence instead of wasting resources and worrying about external issues.
\end{abstract}

Key words: porter's forces, resource-based strategy, competitiveness, performance, hotel, developing region, Indonesia

$* \quad * \quad * \quad * \quad * \quad *$

\section{INTRODUCTION}

The debates over strategic management center on two concepts, or the inward-outward "pendulum swing" (Hoskisson et al., 1999). The first was Michael Porter advocating the importance of external focus, advancing the industrial-organization view (I/O), with five forces and generic strategy (Lewis, 1981; Porter, 1979). The second was the Birger Wernerfelt resource-based view (RBV), promoting internal excellence (Grant, 1991; Wernerfelt, 1984). This study extends the discussions of both streams in the hospitality business context.

Several studies conduct this debate in service terms, e.g. (Rodríguez-Victoria et al., 2017; Tsai et al., 2009). However, their proposed models mostly attribute resource advantages to competitive or destination factors but do not test these factors independently of one another. Thus, this study extends their papers by comparing these prominent strategic theories to establish whether either set of circumstances can leverage hotels' competitive advantages and performance. This paper also contributes to the discussion of this topic from its locus of assessment (Kalnins, 2016).

Most studies testing the empirical evidence of the two schools of thought take place in economically advanced areas. Rarely have researchers taken the experience of a recently growing region in the context of tourism activities of the hospitality business. Hence, this study aims to investigate the topic through the experience of Makassar, South Sulawesi, and for specific reasons. It is geographically located in Indonesia's centre and has experienced growing popularity as the hub of East and West Indonesia. Old hotels were having a hard time fighting the newcomers, equipped with new facility offers and innovation (Campo et al., 2014). This study extended previous studies with the added factors of service quality and infrastructure as the foundation of hotel competitiveness (Chang and Sokol, 2020; Ray et al., 2004; Sánchez-Pérez et al., 2020). We also contributed by designing a formative measurement to reflect the ideal presentation of the proposed relationships, an element inadequately addressed in past studies (Becker et al., 2012; Sarstedt et al., 2019). This paper also presents hotel managers' perceptions in a simple interview to provide extra arguments for this research's statistical findings.

\section{STRATEGIC SERVICE COMPETITIVENESS}

This study raises the issue of performance measurement through services management in the hospitality business. Hotels as a service business need a measurement system that considers a service business's nature instead of using efficiency scales developed for manufacturing companies. Grönroos (1994) argues that service management is a concept involving various interactions, and the use of scientific management in its assessment is insufficient to dissect the breadth of dimensions of this topic. Another reason is that service companies face competition in the service sector; hence, it is

\footnotetext{
* Corresponding author
} 
critical to understand and manage service elements in relationships with customers to achieve competitive advantage (Mody et al., 2019; Salguero et al., 2019). Service business knowledge differs from manufacturing companies (MartinezMartinez et al., 2019; Sayangbatti, 2021), so measuring hotel competitiveness needs to be fine-tuned to appreciate the sector's core nature and competence. Debates over the concept of competitiveness are very diverse in the academic realm. Factors deemed as sources of strategic advantage are resources (Grant, 1991; Wernerfelt, 1984), organizational structures (Peters, 2011), competitive environment (Lewis, 1981; Porter, 1979), the balance of systems (Mintzberg and Waters, 1990), suitability of the internal structure and its environment (Powell, 1992a), system intelligence (Ghoshal and Kim, 1987), and added value (Kogut, 1985). These different criteria provide a glimpse of perceptions about how different goal settings and types of organizations yield different assumptions about competitiveness. One of the hotel industry faces its customer service; thus, the quality of customer service would be the crucial factor in service offerings (Hanzaee and Mirvaisi, 2011; Kashif et al., 2018). Differentiation also emerged in the ways good hotels serve their customers and how factors proposed as tangible - e.g., room and front desk, food and recreation, or security (Chu and Choi, 2000; Lee, 2015) - can please the eyes. This study then posits service quality and infrastructure as essential elements to make a hotel stand out from the competition. Hotel competitiveness would ultimately become the foundation to achieve better corporate performance (Campo et al., 2014; Mashika et al., 2021; Rodríguez-Victoria et al., 2017; Tavitiyaman et al., 2011), and thus:

H1: Service competitiveness significantly boosts the performance of hotels.

\section{External Forces}

Taking its lead from structure-conduct-performance (SCP) Broude and Bain (1957) and Mason (1939), the external focus approach was the first to put the spotlight on strategic management (Hoskisson et al., 1999). This thought was led by Michael E. Porter's seminal article, in which he conceptualizes five vital forces in competitive firms, namely: (1) threat of newcomers; (2) customer bargaining power; (3) distributors' bargaining power; (4) the threat of substitutive products; and (5) rivalry between existing companies (Porter, 1980:4). He believed that the organization that possessed the most exceptional ability to control its external environment would be the one that potentially emerged victorious over the competition. Critiques of this concept came from at least two streams: firstly, the challenge from internal-excellence proponent theories (Grant, 1991; Wernerfelt, 1984); secondly, the advancement of digitalization, globalization, and deregulation has granted more convenient channels to establish customer bases by cheaper means. This access development is contrary to (Lewis, 1981) notion that suppliers' and customers' bargaining powers were challenging to manage. As the access to technology opened up, customers were more informed about what they wanted, and they became better able to express their preferences. This more efficient information led to a more stable selection of brands and decreased customer bargaining; being more knowledgeable made them more ready to make decisions. Customers bargain more when they want to negotiate further, but the increased supply of digitalised information contributed to minimising this constraint. Globalisation and digitalisation have also provided more accessible ways to obtain resources from around the globe. It has been getting easier to shift from one supplier to another, or even to open factories abroad. Outsourcing jobs overseas has also potentially reduced demand from domestic suppliers (Garetto, 2013). These situations have further reduced the bargaining power of suppliers, as access to resources has been significantly reconfigured.

Porter originally designed the five forces in the context of manufacturing firms; however, the hotel industry context requires adjustment. External forces in the hospitality business include the competition phenomenon. Intense competition among hotels, threats of new hotel establishments, or the capability of hotel customers to bargain for services offered are considered to affect the competition factor for hotels significantly. This study eliminated two of Porter's forces due to their minimum - or less significant - effect on the hotel industry: substitution threats and distributor bargains. The hotel does not have a substitute offering a similar service, and the nature of the hotel industry reduces the need for suppliers, unlike among its manufacturing counterparts (Tavitiyaman et al., 2011). These considerations led to an adjustment in Porter's five forces, as used in external factor measurement. Several studies have explored these issues in their investigations. A study by (Schmalensee, 1985) was the first to empirically assess and support the impact of external factors on a firm's performance (Wernerfelt and Montgomery, 1988). Rumelt (1991) was an early contender to Schamalansee's work by comparing his results to those based on firm-specific elements. He found the industry effect to be positively associated with profitability, but the result was relatively small compared to internal factors. Further studies discovered varied results in support of both theories (Hawawini et al., 2005; Tavitiyaman et al., 2011) and thus:

H2: Hotels with substantial control over their external forces would improve competitiveness.

H3: Hotels able to administer their external forces would achieve higher corporate performance.

H4: The relationship between external forces, competitiveness, and hotels' performance would follow indirectly.

\section{Service-Based Resources}

The resource-based view theory (RBV), the seminal work of Wernerfelt (1984), was first introduced as the contender to Porter's external focus. Initially, the inspiration came from Chester Barnard in 1983, Philip Selznick in 1959, or Edith Penrose in 1959 (Hoskisson et al., 1999). This theory focused on the effort to possess strategic resources to create a hardto-get advantage over competitors (1984). The possession of hard-to-imitate human resources, skills, or marketing would present as the key to achieving distinctive competencies, leading to competitiveness (Bolívar-Ramos et al., 2012; MartínRojas et al., 2017; Palacios-Marqués et al., 2019). The service-based resource was a construct developed to represent RBV but in the hospitality business. Given the different natures of service and manufacturing, the need to rearrange the 
investigation in the industrial context must not be compromised. The proposal of RBV also lay in the product development conversation; thus, the service realm required a different approach. Barney $(1991 ; 2001)$ divided excellent resources into a range of characteristics, such as valuable, rare, inimitable, and non-substitutable (Barney, 1991; Barney, 2001). In the context of the hotel business, the potential of excellent resources is visible in terms of room cleanliness or the professional appearance of employees (Nieves et al., 2014; Silva et al., 2017). This study follows the contextualization of excellent service, as measured by how hotels create a continuous climate for providing exceptional service (He et al., 2011) and investment to enrich their customer service offerings (Ray et al., 2004). It is expected that these two dimensions could lead to competitiveness and corporate performance (Mashika et al., 2021). The resource-based view has become a leading approach to discussing the competitiveness of companies. The argument is based on the empirical evidence proving its effectiveness as a more reliable source of competitive advantage and excellent performance than the external focus approach in hotel competition (Leonidou et al., 2013; Molina-Azorín et al., 2015). Thus, we proposed these hypotheses:

H5: $\quad$ Hotels possessing excellent resources would be positively related to hotel competitiveness

H6: $\quad$ Excellent service-related resources would be positively associated with hotel performance

H7: A hotel's excellent resources would lead to hotel performance indirectly through hotel competitiveness

\section{MATERIALS AND METHODS}

\section{Sample}

This study used a quantitative method to answer research questions to accept or reject the proposed hypotheses. To obtain strategic perception, the respondents had to be managers. Thus, we arranged to request letters from the faculty to confirm the study's legitimacy and avoid suspicion from the firms. This measure was imperative in meeting the firms' need for formality and the perception that firms' strategies were highly classified. By this means, this study managed to record responses from 204 hotel managers in Makassar from 62 out of 71 hotels. This sample size was slightly smaller than the indicator rule (Hair et al., 2010), but large enough, given that the responses were more extensive than the 200 cut-off point for structural-equation-modeling analysis to obtain generalization (Boomsma, 1985; Kline, 1998). No data went missing, as this study used Google Forms to ensure precision. The description of the samples is set out in Table 1.

\section{Measures}

This study employs the two-stage approach of partial-least-square structural equation modeling (PLS-SEM). This nonparametric tool aims to analyze the data and achieve a parsimonious model by repeating the indicators' use in the dimensions to obtain the latent variable score (Sarstedt et al., 2019). The latent variable became the single factor data in the final analysis. The structural model uses higher-order components (HOC) comprising ten dimensions containing 22 indicators on a six-point Likert scale. This study also utilizes the formative-reflective HOC model. Specifically, the highorder construct of strategic entrepreneurship is reflective, while the other variables are formative (Figure 1).

This study follows previous research to construct the items and translate them into Indonesian to assure readability. The variable of external forces follows Porter's five forces (1979) but deletes the dimensions of distributor bargaining power and the threat of substitutes because both have little effect on the hotel industry. These deletions leave rivalry, customer bargaining, and new entrants as the external forces (Tavitiyaman et al., 2011).

The following construct is service-based resources. It follows the resource-based-view approach (Barney, 1991; Grant, 1991; Wernerfelt, 1984) modified to appreciate the different nature of the service industry compared to the manufacturing sector. Misspecification of measurements between manufacturing and service could lead to what Shostack (1977) calls a "myopic" response. Thus, some critical dimensions of service firms' resources are the service climate, investment in customer service, and technical support for customer service (He et al., 2011; Ray et al., 2004).

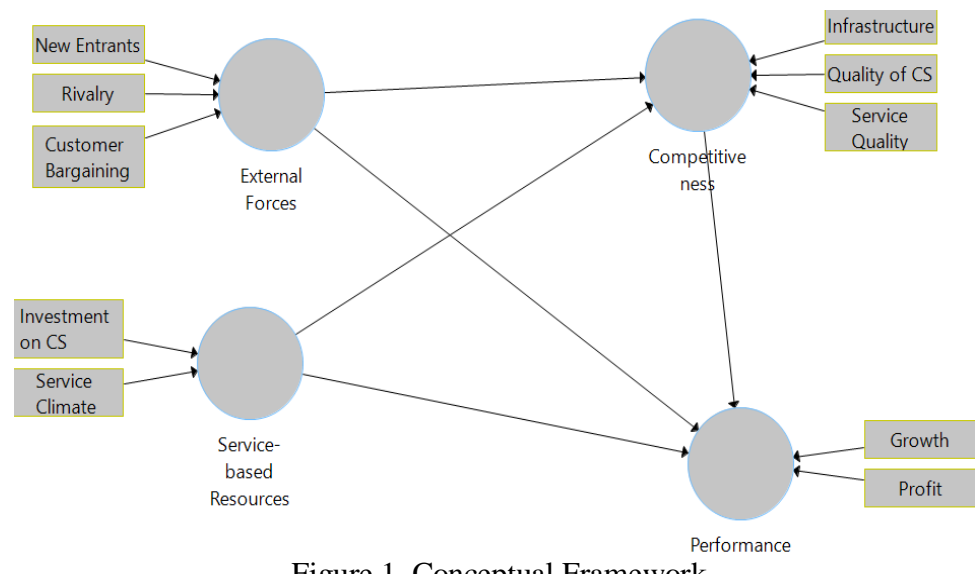

Figure 1. Conceptual Framework
Table 1. Descriptive Backgrounds

\begin{tabular}{|c|c|c|c|c|c|}
\hline Descriptions & $\mathbf{n}$ & $\%$ & Descriptions & $\mathbf{n}$ & $\%$ \\
\hline \multicolumn{3}{|c|}{ Sex } & \multicolumn{3}{|l|}{ Positions } \\
\hline Male & 112 & 54.9 & GM & 24 & 11.8 \\
\hline Female & 92 & 45.09 & Accounting & 27 & 13.2 \\
\hline \multicolumn{3}{|l|}{ Age } & HRD & 32 & 15.7 \\
\hline $18-30$ & 49 & 24.01 & Marketing & 25 & 12.3 \\
\hline $31-45$ & 123 & 60.02 & Division Manager & 38 & 18.6 \\
\hline $46-60$ & 32 & 15.6 & \begin{tabular}{|l|} 
Supervisor \\
\end{tabular} & 49 & 24 \\
\hline $60>$ & & & other & 9 & 4.400 \\
\hline \multicolumn{3}{|l|}{ Education } & \multicolumn{3}{|l|}{ Tenure } \\
\hline High school & 32 & 15.6 & $1-3$ years & 41 & 20.1 \\
\hline D1 & 10 & 4.9 & $3-6$ years & 37 & 18.1 \\
\hline D3 & 42 & 20.5 & $7-10$ years & 37 & 18.1 \\
\hline Bachelor & 120 & 58.8 & $>10$ years & 89 & 43.6 \\
\hline
\end{tabular}

To measure competitiveness, we still follow the work of (Ray et al., 2004) in employing the quality of customer service as one of its essential factors. However, that work investigated the insurance sector, while this study is on the hotel industry. Therefore, it was decided to add dimensions to leverage the measurement. As hotels' profitability is the function 
of their services, they must provide excellent service in every part of their business to add value to their parent companies (Kim and Oh, 2004). Hence, this study adds service quality as another competitiveness factor (Choi and Chu, 2001). Competitive firms have to be dynamic enough to assimilate significant changes. By that reasoning, this study also employs the dynamic capabilities in its measurements (Teece et al., 1997). Finally, this paper adds another critical factor in hotels' competitiveness, i.e., their infrastructure or a hotel's ambiance (Choi and Chu, 2001). A study using big data also supports infrastructure in the measurements (Xiang et al., 2015). Measuring the hotels' performance was slightly tricky. Most hotels were self-owned and reluctant to share financial or strategic data with the authors, so the study collected performance data from the perspective of hotel managers. This paper assesses how managers perceive their efficiency, growth, and profit to measure performance (Li et al., 2009), and compiled in the conceptual framework in Figure 1.

\section{RESULTS AND DISCUSSION}

This study approached 71 hotels in Makassar and obtained 204 good return questionnaires. These managers vary in their positions, with the descriptive information in Table 1. This study uses combinations of formative and reflective variables and dimensions, as shown in Figure 1. Most of them are formative, meaning the arrows of relationships point towards the variables and do not covary or correlate, as is usually accepted in covariance-based structural equation modeling (CB-SEM) like AMOS or Lisrel. Thus, this study employs SEM-PLS, as this technique allows the combination of formative and reflective measurements (Lowry and Gaskin, 2014). All items, dimensions, and constructs in this study are formative types, as their forms cause the variables' presence.

In the analysis, this study constructs higher-order components (HOC) in the model. Hair defines this process as summarising the lower-order indicators into a single multidimensional higher-order construct (Sarstedt et al., 2019). The first variable, external forces, follows Porter's five forces but is slightly modified to employ only rivalry, new entrants, and customer bargaining. This paper does not use distributor bargaining or substitutes, as the hotel industry lacks minimum exposure to those forces (Tavitiyaman et al., 2011). Thirdly, resource-based service is a construct developed by (Ray et al., 2004) to capture potential strategic resources in a service setting, such as service climate, investment in customer service, and technological support for customer service. There are two endogenous variables, competitiveness, and performance. Competitiveness takes the role as a mediating variable between the previous three exogenous variables and hotel performance. This study recognizes competitiveness in terms of several conditions, particularly the quality of customer service - following the Harvard Business School survey that places customer service at the top of pushing firms' success (Garrad and Chamorro-Premuzic, 2016). Secondly, service quality is necessary for every service firm, as it becomes the fundamental factor in every operation (Parasuraman et al., 1985). The next is an infrastructure that ensures service firms provide appropriate tangible offerings to customers (Choi and Chu, 2001). Finally, this study proposes dynamic capabilities as an essential competitive factor that enables a company to incorporate internal competencies and external conditions into strategic decision-making (Hodgkinson and Healey, 2011; Teece, 2019; Teece et al., 1997). Finally, this study follows (Li et al., 2009) to measure service firms' performance through managers' perceptions of profitability and growth. In the analysis, we conduct lower and higher measurement models separately, aware of the consequences of employing the twostage and repeated-indicator approach (Sarstedt et al., 2019). The results of the lower model assessment are in Table 2.

Table 2. Measurement Specifications of Lower-Order Components

\begin{tabular}{|c|c|c|c|c|c|}
\hline $\begin{array}{c}\text { Formative } \\
\text { LOC }\end{array}$ & indicators & rho_- & VIF & $\begin{array}{l}\text { loading } \\
\text { /weight }\end{array}$ & $\begin{array}{c}\text { t- } \\
\text { value }\end{array}$ \\
\hline \multirow{2}{*}{$\begin{array}{l}\text { Customer } \\
\text { bargaining }\end{array}$} & CB1 & \multirow{2}{*}{1.000} & 1.066 & $0.882 / 0.761$ & 8.234 \\
\hline & CB2 & & 1.066 & $0.675 / 0.486$ & 4.255 \\
\hline \multirow{2}{*}{ New Entrants } & & \multirow{2}{*}{.000} & 1.161 & & 5.738 \\
\hline & NE2 & & 1.161 & 0.762 & 3.375 \\
\hline \multirow{2}{*}{ Rivalry } & & \multirow{2}{*}{1.000} & 1.101 & 0.61 & 2.684 \\
\hline & & & 1.109 & & 6.114 \\
\hline \multirow{2}{*}{$\begin{array}{l}\text { Service } \\
\text { climate }\end{array}$} & & \multirow{2}{*}{1.000} & 1.080 & 703 & 12.129 \\
\hline & & & 1.080 & 0.73 & 7.720 \\
\hline \multirow{2}{*}{$\begin{array}{l}\text { Investment in } \\
\text { Cust. Service }\end{array}$} & & \multirow{2}{*}{1.000} & 1.005 & .456 & 4.589 \\
\hline & & & 1.005 & 0.92 & 7.661 \\
\hline \multirow{2}{*}{$\begin{array}{c}\text { Quality of } \\
\text { Cust. Service }\end{array}$} & & \multirow{2}{*}{1.000} & 2.685 & 622 & 7.459 \\
\hline & QCS2 & & 2.435 & $0.90^{\circ}$ & 5.240 \\
\hline \multirow{2}{*}{$\begin{array}{l}\text { Service } \\
\text { Quality }\end{array}$} & & \multirow{2}{*}{1.000} & 2.056 & 0.883 & 5.711 \\
\hline & & & 2.343 & 0.946 & 8.996 \\
\hline \multirow{2}{*}{ Infrastructure } & & \multirow{2}{*}{1.000} & 1.381 & $0.797 / 0.638$ & 9.415 \\
\hline & INF2 & & 1.356 & 0.787 & 8.852 \\
\hline \multirow{4}{*}{ Profit } & PR1 & \multirow{2}{*}{1.000} & 2.302 & $0.846 / 0.314$ & 7.146 \\
\hline & PR2 & & 2.773 & $0.834 / 0.310$ & 6.840 \\
\hline & PR3 & \multirow[b]{2}{*}{1.000} & 2.037 & $0.887 / 0.316$ & 7.562 \\
\hline & & & 1.544 & $0.742 / 0.263$ & 6.496 \\
\hline \multirow{2}{*}{ Growth } & & \multirow{2}{*}{1.000} & 1.387 & $0.809 / 0.513$ & 6.543 \\
\hline & GT2 & & 1.503 & $0.889 / 0.658$ & 8.983 \\
\hline
\end{tabular}

Table 3. Measurement Specifications of High Order Components

\begin{tabular}{|c|c|c|c|c|c|c|}
\hline $\begin{array}{c}\text { HOC } \\
\text { Constructs }\end{array}$ & LOC & $\begin{array}{r}\text { rho } \\
\text { A }\end{array}$ & VIF & loading & Weight & $\begin{array}{c}\mathrm{T} \\
\text { Statistics } \\
\end{array}$ \\
\hline \multirow{3}{*}{$\begin{array}{l}\text { External } \\
\text { Forces }\end{array}$} & $\begin{array}{l}\text { Customer } \\
\text { Bargaining }\end{array}$ & \multirow{3}{*}{1000} & 1.366 & 0.801 & 0.438 & 3.206 \\
\hline & New Entrants & & 1.266 & 0.823 & 0.552 & 4.579 \\
\hline & Rivalry & & 1.143 & 0.600 & 0.324 & 2.526 \\
\hline \multirow{2}{*}{$\begin{array}{c}\text { Service-based } \\
\text { Resources } \\
\end{array}$} & Investment in CS. & \multirow{2}{*}{1000} & 1.737 & 0.789 & 0.262 & 1.955 \\
\hline & Service Climate & & 1.737 & 0.980 & 0.809 & 7.468 \\
\hline \multirow{3}{*}{$\begin{array}{l}\text { Competi- } \\
\text { tiveness }\end{array}$} & Quality of CS.t & \multirow{3}{*}{1000} & 2.147 & 0.885 & 0.389 & 4.445 \\
\hline & Service Quality & & 1.882 & 0.852 & 0.379 & 4.657 \\
\hline & Infrastructure & & 1.712 & 0.842 & 0.395 & 5.571 \\
\hline \multirow{2}{*}{ Perfor-mance } & Growth & \multirow{2}{*}{1000} & 1.519 & 0.829 & 0.689 & 7.244 \\
\hline & Profit & & 1.519 & 0.938 & 0.426 & 3.839 \\
\hline
\end{tabular}

Table 4. The Summary of Significance and Relevance Tests

\begin{tabular}{|l|c|c|c|}
\hline \multicolumn{1}{|c|}{ Relationship } & T Statistics & P Values & Effect Size \\
\hline Competitiveness -> Hotel Performance (H1) & 6.828 & 0.000 & 0.571 \\
\hline External Forces -> Competitiveness (H2) & 8.427 & 0.000 & 0.382 \\
\hline $\begin{array}{l}\text { External Forces -> Hotel Performance (H3) } \\
\begin{array}{l}\text { External Forces -> Competitiveness -> } \\
\text { Hotel Performance (H4) }\end{array}\end{array}$ & 1.559 & 0.119 & 0.102 \\
\hline $\begin{array}{l}\text { Resource-based Services -> } \\
\text { Competitiveness (H5) }\end{array}$ & 11.421 & 0.000 & 0.531 \\
\hline $\begin{array}{l}\text { Resource-Based Service -> Hotel } \\
\text { Performance (H6) }\end{array}$ & 0.826 & 0.409 & 0.061 \\
\hline $\begin{array}{l}\text { Resource-Based Service -> } \\
\text { Competitiveness -> Hotel Performance (H7) }\end{array}$ & 5.644 & 0.000 & 0.304 \\
\hline \multicolumn{4}{|l|}{ Adjusted R ${ }^{2}$ to Competitiveness: 0.526; Adjusted R ${ }^{2}$ to Performance: 0.439} \\
\hline
\end{tabular}


This study anticipates potential common method bias by observing all items' variance inflation factors (VIF) (Podsakoff et al., 2003). The calculation finds no presence of such a problem, as all scales are lower than 3 in the VIF (Kock, 2015, 2017). As this study uses several dimensions, comprising indicators in each variable, higher-order constructs (HOC) in SEM-PLS are the selected statistical assessment in this article. HOC allows the generalization of lower and complex indicators into single dimensions and increases theoretical parsimony (Hair et al., 2019). This study employs formative constructs in all of its higher- and lower-order components. Thus, the model specification has to report the convergent validity, collinearity, and significance and relevance of the outer weights (Sarstedt et al., 2019). The statistical analysis in Table 2 demonstrates that the model meets all requirements. The data is valid convergent with $\rho \mathrm{A} 1$, indicating perfect composite reliability. The VIF is above 0.2 and lower than 3 , implying no multicollinearity. The loading, weight, and tvalue are very substantially above the threshold. This discovery supports the use of LOC and could proceed to the HOC model specification. Running the HOC model in this study requires two approaches. Firstly, this study runs the repeated indicator approach, where we reassign all low-order indicators to their HOC. For instance, the external forces' variable comes from three lower-order constructs: customer bargaining, rivalry, and new entrants. These three dimensions contain six items from six formative indicators. These six items are then formed as the data in its HOC of external forces. The process is the initial step in obtaining the latent scores of all LOC. This single-item score represents all LOC. Secondly, the two-stage approach uses that single factor in the path analysis. The analysis of HOC in PLS-SEM has the exact requirements as its LOC counterpart, i.e., convergent validity, collinearity, weight, and the significance and relevance of the model (Sarstedt et al., 2019). The specifications of high-order components are visible in Table 3.

Table 3 reveals that our model is valid convergent, as seen from its $\rho \mathrm{A}$ of 1 , indicating perfect composite reliability. The collinearity is higher than 0.2 and lesser than 3 to support the absence of multicollinearity. The loading factors are also higher than 0.6, with substantial weight as well as a t-value. Only investments in customer service are slightly lower than the cut-off value of 1.96; however, its loading is above 0.7, where retainment in the model is advisable (Hair et al., 2019). All these results confirm the model's usability so that it can proceed to the structural model evaluation. The Smartpls software also provides a tool of the goodness of fit in its results, despite using a variance instead of covariance-based structural equation modelling (CB-SEM) in AMOS or Lisrel. Thus, we also report the standardized root mean square (SRMR) of 0.046, lower than 0.05, and the normed fit index (NFI) of 0.928 , higher than the expected threshold of 0.90 . The quality of all statistical outer model requirements provides confidence in the model fit. Despite Henseler and Sarstedt (2013) stating that the goodness of fit function in PLS-SEM only explains the different data set as all pre-tests meet the requirements, the analysis shifts to the path coefficients and the bootstrapping results. The summary of statistical tests are in Table 4.

The competition in providing excellent service to customers is essential to every hospitality business, even more so in the hotel industry. A developing region's experience provides a framework for understanding the reality of strategy debates from another perspective. This study finds that the competitiveness of hotels in service quality, the quality of that, and infrastructure are the most critical drivers of hotel performance. This result confirms Hypothesis 1 that the competitiveness of hotels is the most pivotal driver of performance. This finding aligns with previous studies highlighting the importance of identifying firms' competitive advantage (Chi, 2018; Pradana et al., 2020). The very reason is that competitive advantage lies in adding value to a customer's experience (Vo and Chovancová, 2019; Wang et al., 2020). The impact of strong customer perception leads to substantial financial performance in the long run, despite obscured outcomes in the short term (Bernhardt et al., 2000). This finding supports the use of different competitiveness constructs to appreciate the service industry.

This study confirms the second hypothesis on the effect of external focus strategy in achieving competitiveness. This finding corresponds with Schmalensee's (1985) seminal empirical research and other studies, which examined the industry's impact on the creation of corporate competitiveness (Molina-Azorín et al., 2015). Further study in SMEs and the hotel industry supports this competitive strategy (Wang et al., 2012). Hotels that manage to control their superior bargaining power against customers while adaptable to their rivals and newcomers will yield a better position in the competition. It is clear that customer demands are costly; the ability to negotiate them while not compromising the service offered would be a strong basis of external adaptability. Readjusting the position against rivals or newcomers is also crucial in saving fortunes (GonzálezRodríguez et al., 2018). New hotel establishments and competition among old competitors demonstrate the pressures of the external environment. Old hotels find themselves having a hard time landing a business contract for meetings, incentives, conventions, and exhibitions (MICE), despite the considerable market potentiality of Makassar as an essential hub at the center of Indonesia. These findings are in line with the concerns of some managers of old hotels who state:

"The hardest thing in the hotel business today is the competition between hotels in the region. All hotels have provided equal services because the service procedures are standardized and alike. We are lucky to be located near a shopping center. It is even worse with the hotel association ruled by big hotels designing the rules to their benefits in the establishment of new hotels" (general manager of three-star hotel A).

"The hotel association does not play a positive role. New hotels with high star categories but applying rates nearly equivalent to small hotels are eroding our revenue streams. The hotel association that was supposed to tackle this issue was ambiguous because the head of the association also widened its market share by establishing a new big hotel with a rate equivalent to our small hotel" (general manager of three-star hotel B).

These two managers concurred on the current competition that has grown into a price war. The classifications of starred hotels in terms of their rates are vague, with five-star hotels at the price of three-star hotels. Porter (1979) argues that this kind of rivalry is not a stroke of bad luck but suggests it as a way for businesses to find the best point to safeguard their position in the competition. The opinions of hotel managers reinforce Porter's concepts and support the findings of this study around Hypothesis 2. The third hypothesis, concerning the direct relationship of external forces to 
hotel performance, is not endorsed by its critical value. Several studies highlight the mediation mechanism of other variables towards implementation and provide reasons for rejecting the third hypothesis (O'Cass and Ngo, 2012; Ray et al., 2004; Tavitiyaman et al., 2011). Despite being significant, the relevance of external forces is still below the focus on internal excellence. This study finds support for the fifth hypothesis. Internal excellence in the form of service-based resources significantly increases hotels' competitiveness. However, the sixth hypothesis, regarding its direct relationship with performance, is not supported. These findings indicate that the exact mechanism of external and internal strategies signifies a mediation channel. The output of PLS-SEM reveals significant indirect relationships between predictors and predicts variables as in Hypotheses four and seven. Internal factors are also the most relevant factors in achieving good performance through competitiveness rather than external forces.

Despite the managerial concerns over external competition, statistical testing provides evidence of the superiority of internal excellence. Starting from Rumelt (1991), many empirical works support the critical role of possessing valuable, rare, and unique resources (Grant, 1991; Martín-Rojas et al., 2017). This study's statistical tests follow these predecessors in establishing that internal excellence is the best strategy among the rapidly growing competition. Firms must allocate their resources wisely to strengthen their core competence (Dudney, 1997), to obtain distinctive competencies (Hitt and Ireland, 1985; Smart and Conant, 2011). The appreciation of the nature of service must be the strategic priority instead of using manufacturing efficiency measurements to secure future performance (Dogru and Sirakaya-Turk, 2016; Kurniansyah et al., 2021). Shostack (1977) argued that wrong measures of the service industry could lead to a "myopic" view of its true nature. The service-dominant logic that followed this proposition suggests a different treatment between service and ethical selling by identifying core competencies and potential customers, enhancing specific relationships with those customers, and evaluating performance feedback (Alwi et al., 2021; Grönroos, 2006). Strengthening the service logic based on competitive resources would ultimately lead to human resources' critical value, acting as a distinctive variation (Palacios-Marqués et al., 2019; Smart and Conant, 2011). The study follows the propositions by measuring service-based resources based on service climate and customer service investment. Firms with a healthy and positive service climate require a specific human-resource investment to enhance their service offers (Ehrhart et al., 2011). These behaviors appear as innovation, risk-taking, and employees' proactive attitude toward providing excellent service (Alwi et al., 2021; Jawabreh, 2020; Pourfakhimi et al., 2020). They ultimately lead to a better response to customer attitude, service quality, and other competitiveness (Biswas et al., 2020). As a developing region, Makassar supports the resource-based approach to obtain competitiveness in the service industry. In addition to their statistical importance, the interviews reveal a different perspective towards focusing on internal excellence strategy:

"As a chain hotel, we always create a traditional ambiance in the hotel atmosphere. Another thing, I always carried a razor to inspect my employees. Those with long beards would get a cut. Eventually, they would follow the service standards in the hotel, and thus creating service quality. These rules and images have supported our hotel to secure higher than $80 \%$ of occupancy rate" (female assistant of the human resources manager on a three-star hotel C).

The focus on internal excellence has the upper hand in securing the occupancy rate of the old hotel, as what the female supervisor implies. This continuous effort to standardize the service offers provides support for the internal excellence strategy. An organization will achieve its targets if it can satisfy its customers to maximize efficiency and effectiveness compared to competitors (Kurata and Nam, 2010). Appreciating the nature of the service industry in the specific manners outlined above would provide a better narrative to foster knowledge enrichment. This study strongly advises service firms to focus on developing their internal excellence rather than excessively scrutinizing their external focus (Fadli et al., 2021; Wahab et al., 2020). Furthermore, this essential strategy would release more capital towards increasing service firms' capacity for inner excellence (Mahmoud et al., 2021). Another implication is that service firms developing both the region and a competitive environment must stay true to their core excellence and sustainable internal resource (Hemmonsbey and Tichaawa, 2019; Nair and Choudhary, 2016). Either directly or indirectly, all strategies lead to organizational performance or financial performance with different side effects.

\section{Limitations and Recommendation for Further Studies}

This study came with certain limitations. Firstly, the data set was only in one developing region, so generalization must be addressed carefully. Thus, future studies could gain further insight through increasing the area under observation. Secondly, this study encountered issues of collecting more extensive data, as the number of managers is limited. Future studies could gain more information by engaging in a comparison between developing and developed regions. Service competitiveness is a loose term; hence, upcoming articles could further suggest other definitions and measurements of this construct, specific within particular service or hospitality businesses. These explorations will positively enhance the discussion of strategic, more progressive interaction in the hospitality business.

\section{CONCLUSION}

This study indicated that competition in a developing region creates confusion among managers. They exhibit a vital concern over externalities, although internal excellence has been inherently proved to be the crucial factor. This study's findings imply a recommendation for managers to focus more on shaping the core strengths inside their firms, as the statistical findings support this strategic choice. Increasing competitiveness in the quality of service on offer is more crucial than compromising income streams to monitor or anticipate rivals' strategic moves actively. The state tourism agency is also recommended to provide a clear differentiation of hotels' fees relative to their grades as an overcompetitive price war may jeopardize the future of the business and the workforce. 
This article contributes to the debates in the strategic management views by applying it to one of tourism's crucial actors, the hotel industry. This study designs a formative model to measure the managerial responses, bringing further improvement, as previous studies mostly employ reflective measurement.

The second-order measurements applied in the statistical formulation enhance the discussions and add the comparative importance of each dimension to light. The statistical and interview findings reveal a potentiality of confusion of the managers in dealing with competition. This issue may be leveraged in further studies ahead.

\section{Acknowledgment}

The authors claimed that the absenteeism of financial funding could affect this research independence.

\section{REFERENCES}

Alwi, Z., Parmitasari, R.D.A., \& Syariati, A. (2021). An assessment on Islamic banking ethics through some salient points in the prophetic tradition. Heliyon, 7(5), e07103. https://doi.org/10.1016/j.heliyon.2021.e07103

Barney, J. (1991). Firm Resources and Sustained Competitive Advantage. Journal of Management, 17(1), 99-120. https://doi.org/ $10.1177 / 014920639101700108$

Barney, J.B. (2001). Is the resource-based "view" a useful perspective for strategic management research? Yes. In Academy of Management Review 26(1), 41-56. https://doi.org/10.5465/AMR.2001.4011938

Becker, J.M., Klein, K., \& Wetzels, M. (2012). Hierarchical Latent Variable Models in PLS-SEM: Guidelines for Using ReflectiveFormative Type Models. Long Range Planning, 45(5-6), 359-394. https://doi.org/10.1016/j.lrp.2012.10.001

Biswas, C., Deb, S.K., Hasan, A.A.T., \& Khandakar, M.S.A. (2020). Mediating effect of tourists' emotional involvement on the relationship between destination attributes and tourist satisfaction. Journal of Hospitality and Tourism Insights, ahead-ofprint(ahead-of-print). https://doi.org/10.1108/jhti-05-2020-0075

Bolívar-Ramos, M.T., García-Morales, V.J., \& García-Sánchez, E. (2012). Technological distinctive competencies and organizational learning: Effects on organizational innovation to improve firm performance. Journal of Engineering and Technology Management JET-M, 29(3), 331-357. https://doi.org/10.1016/j.jengtecman.2012.03.006

Boomsma, A. (1985). Nonconvergence, improper solutions, and starting values in lisrel maximum likelihood estimation. Psychometrika, 50(2), 229-242. https://doi.org/10.1007/BF02294248

Broude, H.W., \& Bain, J.S. (1957). Barriers to New Competition. The Yale Law Journal, 66(4), 634. https://doi.org/10.2307/794056

Campo, S., Díaz, A.M., \& Yagüe, M.J. (2014). Hotel innovation and performance in times of crisis. International Journal of Contemporary Hospitality Management, 26(8), 1292-1311. https://doi.org/10.1108/IJCHM-08-2013-0373

Chang, H.H., \& Sokol, D.D. (2020). How incumbents respond to competition from innovative disruptors in the sharing economy-The impact of Airbnb on hotel performance. Strategic Management Journal. https://doi.org/10.1002/smj.3201

Chi, T. (2018). Mobile Commerce Website Success: Antecedents of Consumer Satisfaction and Purchase Intention. Journal of Internet Commerce, 17(3), 189-215. https://doi.org/10.1080/15332861.2018.1451970

Choi, T.Y., \& Chu, R. (2001). Determinants of hotel guests' satisfaction and repeat patronage in the Hong Kong hotel industry. International Journal of Hospitality Management, 20(3), 277-297. https://doi.org/10.1016/S0278-4319(01)00006-8

Chu, R.K.S., \& Choi, T. (2000). An importance-performance analysis of hotel selection factors in the Hong Kong hotel industry: A comparison of business and leisure travellers. Tourism Management, 21(4), 363-377. https://doi.org/10.1016/S0261-5177(99)00070-9

Dogru, T., \& Sirakaya-Turk, E. (2016). Stock market valuation of hotel firms' sustainable initiatives. Journal of Hospitality Financial Management, 24(2), 127-132. https://doi.org/10.1080/10913211.2016.1236568

Dudney, R.S. (1997). The core competencies of the force. Air Force Magazine, 80(1), 24-X3. https://doi.org/100-003-757

Ehrhart, K.H., Witt, L.A., Schneider, B., \& Perry, S.J. (2011). Service Employees Give as They Get: Internal Service as a Moderator of the Service Climate-Service Outcomes Link. Journal of Applied Psychology, 96(2), 423-431. https://doi.org/10.1037/a0022071

Fadli, M., Widiarto, A.E., Puspitawati, D., Maharani, D.P., Liemanto, A., Arifien, Z., \& Supriyadi, R.F. (2021). The legal construction of spirituality, ethical and sustainable tourism of Temples in Malang raya, Indonesia. Geojournal of Tourism and Geosites, 35(2), 515524. https://doi.org/10.30892/GTG.35232-679

Garetto, S. (2013). Input sourcing and multinational production. American Economic Journal: Macroeconomics, 5(2), $118-151$. https://doi.org/10.1257/mac.5.2.118

Garrad, L., \& Chamorro-Premuzic, T. (2016). The dark side of high employee engagement. Harvard Business Review, 94(9), $2-4$. https://hbr.org/2016/08/the-dark-side-of-high-employee-engagement

Ghoshal, S., \& Kim, S.K. (1987). Building effective intelligence systems for competitive advantage. Long Range Planning, $20(4), 127$. https://doi.org/10.1016/0024-6301(87)90187-7

González-Rodríguez, M.R., Jiménez-Caballero, J.L., Martín-Samper, R.C., Köseoglu, M.A., \& Okumus, F. (2018). Revisiting the link between business strategy and performance: Evidence from hotels. International Journal of Hospitality Management, 72, $21-31$. https://doi.org/10.1016/j.ijhm.2017.11.008

Grant, R.M. (1991). The Resource-Based Theory of Competitive Advantage: Implications for Strategy Formulation. California Management Review, 33(3), 114-135. https://doi.org/10.2307/41166664

Grönroos, C. (1994). From Marketing Mix to Relationship Marketing: Towards a Paradigm Shift in Marketing. Management Decision, 32(2), 4-20. https://doi.org/10.1108/00251749410054774

Grönroos, C. (2006). Adopting a service logic for marketing. Marketing Theory, 6(3), 317-333. https://doi.org/10.1177/1470593106066794

Hair, J., Black, W., Babin, B., \& Anderson, R. (2010). Multivariate Data Analysis: A Global Perspective. In Multivariate Data Analysis: A Global Perspective 7th).

Hair, J.F., Risher, J.J., Sarstedt, M., \& Ringle, C.M. (2019). When to use and how to report the results of PLS-SEM. In European Business Review 31(1), 2-24. https://doi.org/10.1108/EBR-11-2018-0203

Hanzaee, K.H., \& Mirvaisi, M. (2011). Customer Orientation of Service Employees: A Case Study of Iranian Islamic Banking (Based on COSE Model). International Journal of Marketing Studies, 3(4). https://doi.org/10.5539/ijms.v3n4p130

Hawawini, G., Subramanian, V., \& Verdin, P. (2005). Is performance driven by industry- or firm-specific factors? A reply to McNamara, Aime, and Vaaler. In Strategic Management Journal 26(11), 1083-1086. https://doi.org/10.1002/smj.500 
He, Y., Li, W., \& Keung Lai, K. (2011). Service climate, employee commitment and customer satisfaction: Evidence from the hospitality industry in China. International Journal of Contemporary Hospitality Management, 23(5), 592-607. https://doi.org/10.1108/09596111111143359

Hemmonsbey, J., \& Tichaawa, T.M. (2019). Using non-mega events for destination branding: A stakeholder perspective. Geojournal of Tourism and Geosites, 24(1), 252-266. https://doi.org/10.30892/gtg.24120-357

Henseler, J., \& Sarstedt, M. (2013). Goodness-of-fit indices for partial least squares path modeling. Computational Statistics, 28(2), 565580. https://doi.org/10.1007/s00180-012-0317-1

Hitt, M.A., \& Ireland, R.D. (1985). Corporate distinctive competence, strategy, industry and performance. Strategic Management Journal, 6(3), 273-293. https://doi.org/10.1002/smj.4250060307

Hodgkinson, G.P., \& Healey, M.P. (2011). Psychological foundations of dynamic capabilities: Reflexion and reflection in strategic management. Strategic Management Journal, 32(13), 1500-1516. https://doi.org/10.1002/smj.964

Hoskisson, R.E., Hitt, M.A., Wan, W.P., \& Yiu, D. (1999). Theory and research in strategic management: Swings of a pendulum. Journal of Management, 25(3), 417-456. https://doi.org/10.1177/014920639902500307

Jawabreh, O. (2020). Innovation management in hotels industry in aqaba special economic zone authority; hotel classification and administration as a moderator. Geojournal of Tourism and Geosites, 32(4), 1362-1369. https://doi.org/10.30892/GTG.32425-581

Kalnins, A. (2016). Beyond Manhattan: Localized competition and organizational failure in urban hotel markets throughout the United States, 2000-2014. Strategic Management Journal, 37(11), 2235-2253. https://doi.org/10.1002/smj.2578

Kashif, M., Zarkada, A., \& Ramayah, T. (2018). The impact of attitude, subjective norms, and perceived behavioural control on managers' intentions to behave ethically. Total Quality Management and Business Excellence, 29(5-6), 481-501. https://doi.org/10.1080/14783363.2016.1209970

Kline, R.B. (1998). Software Review: Software Programs for Structural Equation Modeling: Amos, EQS, and LISREL. In Journal of Psychoeducational Assessment 16(4), 343-364. https://doi.org/10.1177/073428299801600407

Kock, N. (2015). Common method bias in PLS-SEM: A full collinearity assessment approach. International Journal of E-Collaboration, 11(4), 1-10. https://doi.org/10.4018/ijec.2015100101

Kock, N. (2017). Common method bias: A full collinearity assessmentmethod for PLS-SEM. In Partial Least Squares Path Modeling: Basic Concepts, Methodological Issues and Applications (245-257). https://doi.org/10.1007/978-3-319-64069-3_11

Kogut, B. (1985). Designing Global Strategies: Comparative and Competitive Value-Added Chains. Sloan Management Review, 26(4), 15-28.

Kurata, H., \& Nam, S.H. (2010). After-sales service competition in a supply chain: Optimization of customer satisfaction level or profit or both? International Journal of Production Economics, 127(1), 136-146. https://doi.org/10.1016/j.ijpe.2010.05.005

Kurniansyah, F., Saraswati, E., \& Rahman, A.F. (2021). Corporate Governance, Profitability, Media Exposure, and Firm Value: the Mediation Role of Environmental Disclosure. Jurnal Minds: Manajemen Ide Dan Inspirasi, 8(1), 69. https://doi.org/10.24252/minds.v8i1.20823

Lee, S.K. (2015). Quality differentiation and conditional spatial price competition among hotels. Tourism Management, 46, 114-122. https://doi.org/10.1016/j.tourman.2014.06.019

Leonidou, L.C., Leonidou, C.N., Fotiadis, T.A., \& Zeriti, A. (2013). Resources and capabilities as drivers of hotel environmental marketing strategy: Implications for competitive advantage and performance. Tourism Management, 35, 94-110. https://doi.org/10.1016/j.tourman.2012.06.003

Lewis, W. (1981). Competitive strategy, Michael E. Porter, The Free Press, New York, 1980. No. of pages: 396. Price: \$15.95. In Strategic Management Journal 2(1). https://doi.org/10.1002/smj.4250020110

Li, Y.H., Huang, J.W., Tsai, M.T. (2009). Entrepreneurial orientation and firm performance: The role of knowledge creation process. Industrial Marketing Management, 38(4), 440-449. https://doi.org/10.1016/j.indmarman.2008.02.004

Lowry, P.B., \& Gaskin, J. (2014). Partial least squares (PLS) structural equation modeling (SEM) for building and testing behavioral causal theory: When to choose it and how to use it. IEEE Transactions on Professional Communication, 57(2), $123-146$. https://doi.org/10.1109/TPC.2014.2312452

Mahmoud, R., Al-Mkhadmeh, A.A., Alananzeh, O.A., \& Masa'deh, R. (2021). Exploring the relationship between human resources management practices in the hospitality sector and service innovation in jordan: The mediating role of human capital. Geojournal of Tourism and Geosites, 35(2), 507-514. https://doi.org/10.30892/gtg.35231-678

Martín-Rojas, R., Fernández-Pérez, V., \& García-Sánchez, E. (2017). Encouraging organizational performance through the influence of technological distinctive competencies on components of corporate entrepreneurship. International Entrepreneurship and Management Journal, 13(2), 397-426. https://doi.org/10.1007/s11365-016-0406-7

Martinez-Martinez, A., Cegarra-Navarro, J.G., Garcia-Perez, A., \& Wensley, A. (2019). Knowledge agents as drivers of environmental sustainability and business performance in the hospitality sector. Tourism Management, 70, 381-389. https://doi.org/10.1016/j.tourman.2018.08.030

Mashika, H., Kudrina, O., Nurgaliyeva, A., Berkova, O., Metil, T., \& Novichkov, V. (2021). Competitiveness of hotel, restaurant and tourism business: Factors and tools. Geojournal of Tourism and Geosites, 36, 681-687. https://doi.org/10.30892/GTG.362SPL16-698

Mason, E.S. (1939). Price and Production Policies. American Economic Review, 29(1), 61-74. http://search.ebscohost.com/ login. aspx ?direct=truedb=bthAN=8699517 site=ehost-livescope $=$ site

Mintzberg, H., \& Waters, J.A. (1990). Tracking Strategy in an Entrepreneurial Firm. Family Business Review, 3(3), $285-315$. https://doi.org/10.1111/j.1741-6248.1990.00285.x

Mody, M., Suess, C., \& Lehto, X. (2019). Going back to its roots: Can hospitableness provide hotels competitive advantage over the sharing economy? International Journal of Hospitality Management, 76, 286-298. https://doi.org/10.1016/j.ijhm.2018.05.017

Molina-Azorín, J.F., Tarí, J.J., Pereira-Moliner, J., López-Gamero, M.D., \& Pertusa-Ortega, E.M. (2015). The effects of quality and environmental management on competitive advantage: A mixed methods study in the hotel industry. Tourism Management, 50, 4154. https://doi.org/10.1016/j.tourman.2015.01.008

Nair, G.K., \& Choudhary, N. (2016). The impact of service quality on business performance in Qatar-based hotels: An empirical study. Journal of Hospitality Financial Management, 24(1), 47-67. https://doi.org/10.1080/10913211.2016.1170559

Nieves, J., Quintana, A., \& Osorio, J. (2014). Knowledge-based resources and innovation in the hotel industry. International Journal of Hospitality Management, 38, 65-73. https://doi.org/10.1016/j.ijhm.2014.01.001

O'Cass, A., \& Ngo, L.V. (2012). Creating superior customer value for B2B firms through supplier firm capabilities. Industrial Marketing Management, 4l(1), 125-135. https://doi.org/10.1016/j.indmarman.2011.11.018 
Palacios-Marqués, D., García, M.G., Sánchez, M.M., \& Mari, M.P.A. (2019). Social entrepreneurship and organizational performance: A study of the mediating role of distinctive competencies in marketing. Journal of Business Research, 101, 426-432. https://doi.org/10.1016/j.jbusres.2019.02.004

Parasuraman, A., Zeithaml, V.A., \& Berry, L.L. (1985). A Conceptual Model of Service Quality and Its Implications for Future Research. Journal of Marketing, 49(4), 41. https://doi.org/10.2307/1251430

Peters, T. (2011). Restoring American Competitiveness: Looking for New Models of Organizations. Academy of Management Executive, 2(2), 103-109. https://doi.org/10.5465/ame.1988.4275515

Podsakoff, P.M., MacKenzie, S.B., Lee, J.Y., \& Podsakoff, N.P. (2003). Common Method Biases in Behavioral Research: A Critical Review of the Literature and Recommended Remedies. Journal of Applied Psychology 88(5), 879-903. https://doi.org/10.1037/0021-9010.88.5.879

Porter, M.E. (1979). Porter 1979 HBR How Competitive Forces Shape Srategy.pdf. In Harvard Business Review (137-145).

Pourfakhimi, S., Duncan, T., \& Coetzee, W.J.L. (2020). Electronic word of mouth in tourism and hospitality consumer behaviour: state of the art. In Tourism Review 75(4), 637-661. https://doi.org/10.1108/TR-01-2019-0019

Powell, T.C. (1992). Organizational alignment as competitive advantage. Strategic Management Journal, 13(2), 119-134. https://doi.org/ $10.1002 / \mathrm{smj} .4250130204$

Pradana, M., Pérez-Luño, A., \& Fuentes-Blasco, M. (2020). Innovation as the key to gain performance from absorptive capacity and human capital. Technology Analysis and Strategic Management, 32(7), 822-834. https://doi.org/10.1080/09537325.2020.1714578

Ray, G., Barney, J.B., \& Muhanna, W.A. (2004). Capabilities, business processes, and competitive advantage: Choosing the dependent variable in empirical tests of the resource-based view. Strategic Management Journal, 25(1), 23-37. https://doi.org/10.1002/smj.366

Rodríguez, V.O.E., Puig, F., \& González-Loureiro, M. (2017). Clustering, innovation and hotel competitiveness: evidence from the Colombia destination. International Journal of Contemporary Hospitality Management, 29(11), $2785-2806$. https://doi.org/10.1108/IJCHM-03-2016-0172

Rumelt, R.P. (1991). How much does industry matter? Strategic Management Journal, 12(3), 167-185. https://doi.org/ 10.1002/smj.4250120302

Salguero, G.C., Gámez, M.Á.F., Fernández, I.A., \& Palomo, D.R. (2019). Competitive intelligence and sustainable competitive advantage in the hotel industry. Sustainability (Switzerland), 11(6). https://doi.org/10.3390/su11061597

Sánchez-Pérez, M., Illescas-Manzano, M.D., \& Martínez-Puertas, S. (2020). You're the Only One, or Simply the Best. Hotels differentiation, competition, agglomeration, and pricing. International Journal of Hospitality Management, 85. https://doi.org/ 10.1016/j.ijhm.2019.102362

Sarstedt, M., Hair, J.F., Cheah, J.H., Becker, J.M., \& Ringle, C.M. (2019). How to specify, estimate, and validate higher-order constructs in PLS-SEM. Australasian Marketing Journal, 27(3), 197-211. https://doi.org/10.1016/j.ausmj.2019.05.003

Sayangbatti, D.P. (2021). Knowledge sharing and service innovation as a key business success of the hospitality industry in Indonesia. Quality - Access to Success, 22(183), 143-147.

Schmalensee, R. (1985). Do markets differ much? In American Economic Review, 75(3), 341-351. https://doi.org/10.2307/1814804

Shostack, G.L. (1977). Breaking Free from Product Marketing. Journal of Marketing, 41(2), 73. https://doi.org/10.2307/1250637

Silva, R., Gerwe, O., \& Becerra, M. (2017). Corporate brand and hotel performance: A resource-based perspective. Journal of Business Research, 79, 23-30. https://doi.org/10.1016/j.jbusres.2017.05.019

Smart, D.T., \& Conant, J.S. (2011). Entrepreneurial Orientation, Distinctive Marketing Competencies And Organizational Performance. Journal of Applied Business Research (JABR), 10(3), 28. https://doi.org/10.19030/jabr.v10i3.5921

Tavitiyaman, P., Qu, H., \& Zhang, H.Q. (2011). The impact of industry force factors on resource competitive strategies and hotel performance. International Journal of Hospitality Management, 30(3), 648-657. https://doi.org/10.1016/j.ijhm.2010.11.010

Teece, D.J. (2019). A capability theory of the firm: an economics and (Strategic) management perspective. New Zealand Economic Papers, 53(1), 1-43. https://doi.org/10.1080/00779954.2017.1371208

Teece, D.J., Pisano, G., \& Shuen, A. (1997). Dynamic capabilities and strategic management. Strategic Management Journal, 18(7), 509-533. https://doi.org/10.1002/(SICI) 1097-0266(199708)18:7<509::AID-SMJ882>3.0.CO;2-Z

Tsai, H., Song, H., \& Wong, K.K.F. (2009). Tourism and hotel competitiveness research. In Journal of Travel and Tourism Marketing 26, 5-6, 522-546). https://doi.org/10.1080/10548400903163079

Vo, N.T., \& Chovancová, M. (2019). Customer satisfaction engagement behaviors towards the room rate strategy of luxury hotels. Tourism and Hospitality Management, 25(2), 403-420. https://doi.org/10.20867/thm.25.2.7

Wahab, A., Abbas, N., Syariati, A., \& Syariati, N.E. (2020). The Trickle-Down Effect of Intellectual Capital on Banks' MacroPerformance in Indonesia. Journal of Asian Finance, Economics and Business, 7(12), 703-710. https://doi.org/10. 13106/JAFEB.2020.VOL7.NO12.703

Wang, C.H., Chen, K.Y., \& Chen, S.C. (2012). Total quality management, market orientation and hotel performance: The moderating effects of external environmental factors. International Journal of Hospitality Management, 31(1), 119-129. https://doi.org/ 10.1016/j.ijhm.2011.03.013

Wang, Y., Anderson, J., Joo, S.J., \& Huscroft, J.R. (2020). The leniency of return policy and consumers' repurchase intention in online retailing. Industrial Management and Data Systems, 120(1), 21-39. https://doi.org/10.1108/IMDS-01-2019-0016

Wernerfelt, B. (1984). A resource-based view of the firm. Strategic Management Journal, 5(2), 171-180. https://doi.org/ $10.1002 /$ smj.4250050207

Wernerfelt, B., \& Montgomery, C.A. (1988). Tobin's q and the Importance of Focus in Firm Performance. The American Economic Review, 78(1), 246-250.

Xiang, Z., Schwartz, Z., Gerdes, J.H., \& Uysal, M. (2015). What can big data and text analytics tell us about hotel guest experience and satisfaction? International Journal of Hospitality Management, 44, 120-130. https://doi.org/10.1016/j.ijhm.2014.10.013

Yong Kim, B., Oh, H. (2004). How do hotel firms obtain a competitive advantage? International Journal of Contemporary Hospitality Management, 16(1), 65-71. https://doi.org/10.1108/09596110410516589

Article history: Received: 01.06.2021 Revised: 18.09.2021 Accepted: 05.10.2021 Available online: 26.11.2021 